DOI: 10.17951/lrp.2016.35.4.79

\author{
ElżBieta Dolata
}

Uniwersytet Rzeszowski

\title{
GALICYJSCY POPULARYZATORZY ZDROWIA I HIGIENY PRZEŁOMU XIX I XX WIEKU
}

\begin{abstract}
Abstrakt: Na przełomie XIX i XX wieku Galicja stała się centrum polskiego ruchu higienicznego, którego celem była poprawa sytuacji higienicznej w kraju. Z jednej strony dzięki autonomii miała większe niż inne zabory możliwości wymiany myśli i doświadczeń, z drugiej zaś trudne warunki życia ludności oraz bardzo zła sytuacja sanitarno-higieniczna miast i wsi dyktowały konieczność radykalnych przedsięwzięć w tym zakresie. W działania na rzecz poprawy warunków higienicznych w Galicji włączyli się polscy higieniści, lekarze i pedagodzy. W artykule zaprezentowano wybrane sylwetki oraz działania popularyzatorskie na rzecz zdrowia i higieny w dwóch ośrodkach: Krakowie i Lwowie. We Lwowie działał autor pierwszego podręcznika higieny szkolnej, pionier myśli higienicznej w Galicji Tadeusz Żuliński. W działalność higieniczną byli zaangażowani ponadto: Józef Żuliński, Edward Madeyski, Mieczysław Tytus Baranowski, Bolesław Adam Baranowski, Bronisław Kaczorowski, Edmund Cenar, Antoni Durski. W Krakowie znaną postacią stał się Henryk Jordan, profesor Wydziału Lekarskiego Uniwersytetu Jagiellońskiego. Oprócz niego w pracę społeczną na rzecz krzewienia higieny byli zaangażowani: Eugeniusz Piasecki, Józef Dietl, Zygmunt Wyrobek.
\end{abstract}

Słowa kluczowe: historia wychowania, higiena, wychowanie higieniczne, ruch higieniczny w Galicji

Na przełomie XIX i XX wieku w Europie rozwinął się intensywny ruch higieniczny, którego celem była poprawa sytuacji sanitarno-zdrowotnej we wszystkich państwach oraz uświadomienie szerokim kręgom społecznym znaczenia odpowiednich warunków higienicznych dla utrzymania dobrego zdrowia.

Źródła ożywienia higienicznego w tym czasie wiążą się głównie z rozwojem kapitalizmu. Industrializacja i kapitalizacja gospodarki, a w konsekwencji 
gwałtowna urbanizacja stworzyły specyficzne potrzeby społeczne. Wśród nich ważną kwestię stanowiły warunki życia, pracy oraz wychowania wpływające na zdrowie ludności. O rozwoju higieny decydowały również pojawiające się często epidemie, które zagrażały zdrowiu ludności i wymagały szybkich środków zaradczych. Jednocześnie rozwój bakteriologii, epidemiologii oraz technik sanitarnych dał możliwość działań profilaktycznych (szczepienia ochronne) i leczniczych, przyczynił się do budowy wodociągów, kanalizacji, centralnego ogrzewania, wentylacji mechanicznej. Zintensyfikowanie działań na rzecz poprawy zdrowia ludności wiązało się także z potrzebami demograficzno-militarnymi. Zwalczanie chorób i poprawa zdrowotności miały wpłynąć bowiem na wzrost liczebności populacji i wzmocnienie państwa (Fijałek 1998, s. 8). Coraz częściej zaczęto więc zwracać uwagę na zachorowalność i śmiertelność ludności. Pojawiły się początki naukowej statystyki medycznej, wzrastała świadomość znaczenia demografii, o czym świadczą pierwsze tabele porównujące liczbę narodzin i zgonów, pojawiające się po 1760 roku (Vigarello 1998, s. 154). Dodatkowo zapobieganie chorobom, troska o zdrowie zyskały wymiar ekonomiczny i polityczny, a ich rolę określano jako „publiczną zdrowotność”. Dążenie do tego, by to państwo było odpowiedzialne za ową publiczną zdrowotność, można odnaleźć w poglądach Jeana Halle i Johanna Petera Franka (Marcinkowski 1988, s. 250). J.P. Frank przyczynił się do popularyzacji na gruncie europejskim terminu „policja medycynalna” rozumianego jako szerokoprofilowe, administracyjne działanie państwa na rzecz zdrowia publicznego i jest uznawany za ojca medycyny szkolnej (Szczepańska 2014, s. 23). Rozwój higieny przyczynił się ponadto do bardziej wnikliwego spojrzenia na praktykę szkolną oraz poszukiwania racjonalnych rozwiązań organizacyjnych, programowych i metodycznych w nauczaniu i wychowaniu. W coraz większym stopniu zdawano sobie sprawę, że podstawą osiągnięć dydaktycznych i wychowawczych jest zdrowie dzieci i młodzieży. Świadomość ta stopniowo narastała i znalazła swój wyraz w zwiększającym się stale zainteresowaniu lekarzy oraz pedagogów problemami higienicznymi i zdrowotnymi uczniów. Przyniosło to konkretne działania zmierzające do przystosowania warunków nauki szkolnej do potrzeb rozwojowych i zdrowotnych dzieci i młodzieży, a więc rozwoju ruchu higienicznego w szkołach.

Międzynarodowe kontakty lekarzy, higienistów i pedagogów, wymiana myśli i doświadczeń w zakresie higieny przyczyniły się do przenikania ruchu higienicznego na ziemie polskie. Tak jak w całej Europie również w Galicji nastąpiła intensyfikacja różnorodnych działań promujących zdrowie i higienę. Tu szczególnie bowiem był widoczny „szalony brak higieny i ogromne odczuwanie jej potrzeb” (Kacprzak 1932, s. 117).

Celem niniejszej publikacji jest ukazanie sylwetek osób zaangażowanych w działania na rzecz podniesienia kultury sanitarnej w Galicji na przełomie XIX i XX 
wieku. Kierunki i zakres przedsięwzięć higienicznych wynikał tu z sytuacji sanitarno-zdrowotnej. Warunki życia mieszkańców Galicji w tym okresie nie zapewniały utrzymania dobrego zdrowia. Brak urządzeń sanitarnych w miastach i wsiach, powszechny brud i brak znajomości podstawowych zasad higieny powodował rozprzestrzenianie się licznych chorób i epidemii, a w związku z tym dużą śmiertelność ludności. Ponadto nieodpowiednie warunki nauki szkolnej przyczyniały się do powstawania u dzieci i młodzieży tzw. „chorób szkolnych”. Stąd działania podejmowane przez władze krajowe, towarzystwa i organizacje oraz pojedyncze osoby na rzecz poprawy warunków sanitarno-zdrowotnych.

Na przełomie XIX i XX wieku w Galicji w działaniach na rzecz upowszechniania zdrowia i higieny przodowały dwa ośrodki: lwowski i krakowski, gdzie w ruch higieniczny włączyli się liczni polscy lekarze, higieniści i pedagodzy.

Nieoceniony wkład w rozwój zainteresowania wiedzą higieniczną oraz wychowaniem fizycznym wśród dzieci i młodzieży wniósł pracujący we Lwowie Edward Madejski. Urodził się w Stratynie nad Sanem w 1832 r. Studiował na Uniwersytecie Wiedeńskim medycynę. Po ukończeniu studiów, jako magister nauk lekarskich, był sekundariuszem Szpitala Powszechnego we Lwowie, a następnie Szpitala św. Łazarza w Krakowie. Jednocześnie był lekarzem sądowym i prowadził powszechne szczepienia ludności przeciw ospie. Szerszemu ogółowi dał się poznać jako autor pracy Dietetyka dzieci oparta na wskazówkach przyrody. Przewodnik $w$ zdrowym pielęnowaniu dzieci od przyjścia na świat aż do dojrzewania (Lwów 1896). Dzieło to było traktowane jako podręcznik higieniczny dla rodziców. Podkreślał w nim znaczenie dla zdrowia, ruchu i ćwiczeń fizycznych. W roku 1870 Madejski uruchomił we Lwowie Zakład Gimnastyczny, oprócz tego w latach 1872-1890 był nauczycielem gimnastyki i higieny w seminariach nauczycielskich męskim i żeńskim we Lwowie. Napisał on pierwszy podręcznik gimnastyki dla szkół Gimnastyka w szkołach ludowych. Instrukcja dla nauczycieli (Lwów 1879) oraz pracę Nauka gimnastyki szkolnej, teoretyczny podręcznik dla uczniów i uczennic seminariów nauczycielskich w szkołach ludowych, pospolitych i wydziałowych (Lwów 1890). Poza tym był autorem podręcznika do higieny dla seminariów nauczycielskich Somatologia i higiena (Lwów 1896). W latach 1879-1906 był przewodniczącym Komisji Egzaminacyjnej dla kandydatów nauczycieli gimnastyki w szkołach średnich i seminariach nauczycielskich we Lwowie oraz wykładowcą anatomii człowieka, fizjologii ruchu, dietetyki i historii gimnastyki na kursach sokolich organizowanych we Lwowie w latach 1883-1884 dla nauczycieli wychowania fizycznego (Cenar 1907, s. 12). Madeyski był także założycielem pierwszego we Lwowie Zakładu Kefirowego, za co 5. Zjazd Lekarzy i Przyrodników Polskich we Lwowie przyznał mu w 1881 r. srebrny medal. Jako teoretyk wychowania fizycznego reprezentował kierunek zdrowotno-higieniczny i był zwolennikiem tzw. gimnastyki racjonalnej. Przyczynił się do rozwoju 
polskiego piśmiennictwa z zakresu wychowania fizycznego i higieny. Madejski zmarł 6 sierpnia 1906 r. we Lwowie (Toporowicz 1974, s. 121).

W działalność higieniczno-zdrowotną we Lwowie byli zaangażowani również bracia Żulińscy. Starszy Tadeusz Żuliński urodził się 30 listopada 1839 r. w Krakowie. Był lekarzem i od 1871 r. pracował w Szpitalu Powszechnym we Lwowie oraz jako lekarz filantrop wśród lwowskiej biedoty. Działał również w wielu instytucjach i organizacjach dobroczynnych. Najważniejsza jednak była jego działalność na polu higieny szkolnej. Przez 13 lat wykładał higienę w prywatnych szkołach żeńskich, wygłaszał publiczne odczyty o tematyce higienicznej. Działał w Towarzystwie Lekarzy Galicyjskich, Towarzystwie Politechnicznym i Towarzystwie Pedagogicznym, z których ramienia walczył o reformę oświatową, a w szczególności o wprowadzenie higieny i gimnastyki do szkół. Czynnie uczestniczył w Zjazdach Lekarzy i Przyrodników Polskich, wygłaszając liczne referaty i stawiając wiele ważnych postulatów, np. zorganizowanie na Uniwersytecie Lwowskim wydziału medycyny. Był członkiem Rady miasta Lwowa; pracując w sekcji sanitarnej, starał się popularyzować wiedzę higieniczną wśród ludności oraz polepszać warunki higieniczne i zdrowotne w mieście (Dolata 2002, s. 210-213). Od 1873 r. T. Żuliński był członkiem Wydziału Lwowskiego Towarzystwa Gimnastycznego „Sokół”, a od 1875 r. do śmierci wiceprezesem tego Towarzystwa. Opublikował wiele artykułów i broszur poruszających zagadnienia higieny oraz propagujących wychowanie fizyczne. W 1881 r. założył pierwsze $\mathrm{w}$ Polsce fachowe pismo poświęcone wychowaniu fizycznemu i higienie - „Przewodnik Gimnastyczny”, i do śmierci pełnił obowiązki jego redaktora. Z ramienia Towarzystwa Pedagogicznego wraz z doktorem Teofilem Garstmanem stworzył we Lwowie w 1883 r. komitet dla Kolonii Wakacyjnych. Od 1884 r. Komitet organizował kolonie dla dzieci w dwóch miejscowościach: Hucie Korostwaskiej dla chłopców i Lisowcach dla dziewcząt, w późniejszych latach również w wielu innych miejscach. Dla kolonii T. Żuliński opracował szczegółowe przepisy lekarsko-higieniczne, przeprowadzał też wstępne badania dzieci zgłaszanych na kolonie i badania kontrolne po powrocie $\mathrm{z}$ wakacji. Wyniki tych badań stanowiły podstawę do studiów naukowych nad zdrowotną wartością kolonii wakacyjnych. Publikował także periodyczne sprawozdania z akcji letniej (Dolata 2002, s. 210-213). W dziejach higieny i pedagogiki polskiej zasłynął jako autor pierwszego oryginalnego podręcznika higieny Higiena szkolna, który wydano pośmiertnie w 1886 r. w Krakowie. Był poza tym autorem wielu interesujących publikacji z zakresu higieny szkolnej oraz artykułów publikowanych w czasopismach pedagogicznych. Tadeusz Żuliński zmarł 18 stycznia 1885 r. we Lwowie (Demel 2000, s. 118-121).

Brat Tadeusza, Józef Anzelm Żuliński (ur. 21 kwietnia 1841 r. w Krakowie), również zaangażował się w działalność higieniczną w Galicji. Pracował przez 35 lat jako profesor nauk przyrodniczych i matematyki w Państwowym Seminarium 
Nauczycielskim Żeńskim we Lwowie. W 1885 r. utworzył Komitet patronujący sprawie tworzenia kolonii wakacyjnych, a w rok później zorganizował pierwszą Kolonię Leczniczą dla dzieci w Rymanowie. Opracował dla niej statut i regulamin, a ponadto od chwili zainicjowania aż do $1904 \mathrm{r}$. był jej dyrektorem. Według statutu Towarzystwa na tygodniowe kolonie lecznicze przyjmowano „dzieci płci obojga, wyznania chrześcijańskiego potrzebujące kuracji w zdrojowiskach w wieku lat 7 do 13, w całości lub w części na koszt ich rodziców lub opiekunów [...] Dzieci dotknięte chorobami zaraźliwymi, umysłowymi lub epilepsją, ranami lub wymagającymi szpitalnego traktowania, do kolonii nie przyjmowano" (Pótwiekowa... 1935, s. 73). Badania lekarskie udowadniały, że pobyt na kolonii przynosił dzieciom olbrzymie korzyści. Stosowane kąpiele mineralno-gazowe, borowinowe przyczyniały się do poprawy ich zdrowia. J. Żuliński pisał: „Jeżeli kolonie wakacyjne w ogóle, nastręczające dziatwie sposobności odzyskania sił nadwątlonych w szkole, są same przez się ważne i pożyteczne, to o ileż ich doniosłość i znaczenie się potęguje, jeśli do higienicznych i pedagogicznych korzyści tych kolonii przyłączymy jeszcze możliwość radykalnego leczenia objawiających się zarodów ciężkich dolegliwości” (Księga... 1892, s. 233). Za przykładem Rymanowa zaczęto organizować kolonie lecznicze dla dzieci w Rabce oraz w Krynicy. Kolonia rymanowska kilkakrotnie była odznaczana na wystawach krajowych (Dolata 2001, s. 27).

Józef Żuliński był również jednym z inicjatorów instytucji korpusów wakacyjnych dla młodzieży szkolnej we Lwowie. Pierwszy taki korpus zorganizowano w 1889 r. dla 345 uczniów szkół średnich. W regulaminie korpusów wakacyjnych czytamy: „Instytucja korpusów wakacyjnych ma na celu podnieść fizyczny i moralny rozwój młodzieży szkolnej, budzić w niej ducha karności, zgody i koleżeństwa. Krzewić zamiłowanie do gier, gimnastyki, chronić wreszcie od zgubnego wpływu ulicy i rozluźnienia, na jakie młodzież pozostawiona samej sobie podczas wakacji, najczęściej jest narażona. Środki do osiągnięcia powyższego celu, prócz moralnego oddziaływania nadzorujących młodzież kierowników są: wycieczki i długotrwałe pochody, musztra, gry i zabawy, gimnastyka i kąpiele" (Regulamin... 1893). Były to więc jednodniowe wymarsze za miasto, połączone z odpoczynkiem i ćwiczeniami ruchowymi na świeżym powietrzu. W każdym roku zgłaszało się coraz więcej chętnych do uczestnictwa w tej formie odpoczynku. Komitet dla Kolonii Wakacyjnych we Lwowie zorganizował w 1890 r. wyprawy dla 800 uczniów, w kolejnych latach liczba uczestników systematycznie rosła, wynosiła nawet 1500 osób (Gutkowski 1893, s. 7). Wzorem Lwowa również w innych miastach galicyjskich zaczęto organizować korpusy wakacyjne.

Józef Żuliński był też autorem kilku prac z zakresu historii naturalnej, m.in.: O nauczaniu historii naturalnej w szkołach ludowych (Lwów 1875), w której poruszył zagadnienia dotyczące zdrowia. Zmarł 6 stycznia 1908 r. we Lwowie (Górski 
1927, s. 12). Obaj bracia, Tadeusz i Józef, zostali pochowani w rodzinnym grobowcu Żulińskich na Cmentarzu Łyczakowskim we Lwowie.

Znaczącą rolę w propagowaniu zdrowia i higieny w Galicji odegrali także bracia Baranowscy. Starszy z nich Bolesław Adam Baranowski urodził się w 1844 r. w Waszkowcach na Bukowinie. Studiował na Uniwersytecie Lwowskim. Do 1871 r. pracował w Gimnazjum Franciszka Józefa we Lwowie, równocześnie działał w Towarzystwie Pedagogicznym (Bruchnalski 1935a, s. 276-277). Po utworzeniu seminariów nauczycielskich pracował w Państwowym Seminarium Nauczycielskim Męskim w Stanisławowie (Meissner 1997, s. 82-92). W 1885 r. uzyskał nominację na krajowego inspektora szkół w Galicji. W 1881 r. stał się jednym z współzałożycieli Towarzystwa Oświaty Ludowej we Lwowie, którego głównym celem było zakładanie czytelni dla ludu, wypożyczalni książek, urządzanie popularnych odczytów, kolportaż tanich książek, czyli szerzenie oświaty, w tym wiedzy z zakresu ochrony zdrowia w środowisku wiejskim (Terlecki 1990, s. 87-96). Od 1882 do końca 1884 r. był redaktorem „Szkoły”, organu Towarzystwa Pedagogicznego. Na łamach czasopisma wiele miejsca poświęcano zagadnieniom higieny szkolnej. Pojawiały się artykuły o warunkach sanitarnych galicyjskich szkół, wyniki badań zdrowia uczniów oraz liczne postulaty zaprowadzenia stałej opieki medycznej w szkołach. Autorem licznych artykułów o tematyce higienicznej był B. Baranowski (Dolata 2010, s. 253-264). Był on również autorem kilku cennych publikacji zwartych z zakresu higieny szkolnej, wśród nich warto wymienić Szkolnictwo ludowe w Galicji w swym rozwoju liczebnym od roku 1868 do roku 1909 z uwzględnieniem stosunków higienicznych (Lwów 1911). W pracy tej domagał się zapewniania dzieciom i młodzieży odpowiednich warunków higienicznych w szkołach, równocześnie przedstawiał ich stan higieniczny, który był daleki od ideału. Zauważył, że większość budynków szkolnych nie nadawała się do użytku, brakowało w nich urządzeń sanitarnych i podstawowego wyposażenia (ławek, tablic, wieszaków na ubrania). Sprzęty, którymi szkoły dysponowały, nie odpowiadały żadnym normom sanitarno-higienicznym. Stąd B. Baranowski apelował do władz szkolnych o poprawę istniejącego stanu. Podkreślał niekorzystny wpływ warunków nauki na zdrowie dzieci i młodzieży (Baranowski 1910, s. 4). Dodatkowo postulował upowszechnienie letniego wypoczynku dla wszystkich uczniów szkół ludowych i średnich. Według niego kolonie letnie zapewniały dzieciom wzmocnienie zdrowia i kondycji fizycznej. Przekonywał, iż przyczynia się do tego odpowiednia organizacja zajęć, odpoczynek na świeżym powietrzu i racjonalne odżywianie (Baranowski 1884, s. 13). B.A. Baranowski zmarł 5 października 1916 r. we Lwowie.

W działania na rzecz upowszechniania wiedzy higienicznej w Galicji był zaangażowany również brat Bolesława, Mieczysław Tytus Baranowski, który urodził się w 1851 r. w Wyżnicy na Bukowinie. Był nauczycielem, a od 1895 r. dyrektorem 
Seminarium Nauczycielskiego Żeńskiego we Lwowie. Był też członkiem Rady m. Lwowa. Jako inspektor lwowski roztoczył opiekę nad niezamożnymi dziećmi, urządzając obiady szkolne i korpusy wakacyjne (Bruchnalski 1935b, s. 282). W latach 1888-1895 pełnił funkcję redaktora naczelnego czasopisma "Szkoła”, później z F. Majchrowiczem redagował miesięcznik „Rodzina i Szkoła”, w którym umieścił wiele artykułów z zakresu wychowania, nauczania, pielęgnowania dzieci. M.T. Baranowski był autorem podręczników dla kandydatów do zawodu nauczycieli szkół ludowych. Na szczególną uwagę zasługują prace z zakresu higieny, np.: Zarys higieny i dietetyki ciała $i$ ducha $w$ zastosowaniu do młodzieży szkolnej i do wieku dziecięcego (Stanisławów 1881), Higiena popularna czyli nauka o warunkach i pielegnowaniu zdrowia (Tarnów 1886), Zarys higieny szkolnej (Lwów 1891) oraz wspólnie z prof. J. Szpilmanem Higiena przystępnie ułożona (Lwów 1891). W wymienionych pracach zwartych oraz licznych artykułach zamieszczonych na łamach prasy pedagogicznej nawoływał społeczeństwo do przestrzegania zasad higieny, nie tylko w szkołach, ale również w życiu codziennym.

Baranowski brał udział w licznych zjazdach oraz kongresach higienicznych i porównywał sytuację higieniczną Galicji i innych państw europejskich. Po wnikliwych obserwacjach stwierdzał liczne polskie niedociągnięcia. W Galicji brakowało powszechnie kanalizacji, wodociągów, kontroli i oceny budownictwa pod względem higienicznym (w tym budynków szkolnych). Dokonywał analiz statystycznych śmiertelności ludności galicyjskiej, uzasadniał dużą liczbę zgonów wśród dzieci i młodzieży złymi warunkami sanitarno-higienicznymi mieszkań, szkół (Baranowski 1894, s. 271). Baranowski wielokrotnie podkreślał trudną sytuację sanitarno-higieniczną szkół galicyjskich i apelował o ich poprawę. Przykładowo w jednym z artykułów pisał: „Ławki mają w przeważającej ilości szkół wymiary, odpowiadające wzrostowi ludzi dorosłych [...] pulpity ławek oddalone bardzo od siedzeń często nie mają żadnego nachylenia, albo nawet mają nachylenie wadliwe w kierunku przeciwnym normalnemu. Siedzenie w takich ławkach przez kilka godzin dziennie powoduje wady postawy" (Baranowski 1888, s. 186). Wielokrotnie wypowiadał się również na temat nieodpowiedniego wyposażenia. W licznych artykułach poruszał ponadto problem przepełnienia klas, przyczyniający się do rozprzestrzeniania się chorób (Baranowski 1885, s. 231). Wyraźnie eksponował negatywne skutki braku higieny na rozwój psychiczny, fizyczny i umysłowy dziecka. W jednej z publikacji czytamy: „Jaka szkoła, taka nasza przyszłość, że wiedza bez zdrowia nic nie ma wartości, i że tylko człowiek zdrowy może dbać o pomyślność swoją, swoich potomków i bliźnich" (Baranowski 1881, s. 95). Krytycznego stanu higieny szkolnej w Galicji dopatrywał się w niskim poziomie i nieznajomości zasad higieny w społeczeństwie oraz w zacofaniu i ignorancji. 
W latach 1887-1895 M.T. Baranowski pełnił funkcję inspektora szkolnego miejscowego we Lwowie. $\mathrm{Z}$ jego inicjatywy powstało we Lwowie 6 nowoczesnych pod względem wymogów ówczesnej higieny szkół, otoczył szczególną opieką dzieci z rodzin najbiedniejszych, urządzając dla nich korpusy wakacyjne i codzienne dożywianie w szkole (Potoczny 1997, s. 105-110). M. Baranowski zmarł 25 listopada 1898 r. we Lwowie (Wspomnienie pośmiertne, s. 483).

W zakresie działań higienicznych należy również wymienić upowszechnianie gimnastyki. Do jej propagatorów należał Antoni Maciej Durski - naczelnik sokolstwa. Urodził się on w Zbarażu w 1854 r., był uczniem E. Madeyskiego. Prowadził kursy dla kierowników sokolich we Lwowie i Krakowie. Był współpracownikiem i przez pewien czas redaktorem „Przewodnika Gimnastycznego” - organu Towarzystwa Gimnastycznego „Sokół”. Obok twórcy organizacji, Jana Dobrzańskiego, był twórcą właściwego programu i systemu sokolego. Opublikował też kilka rozpraw, z których najważniejszą jest opracowanie polskiej terminologii gimnastycznej. Jako uznany fachowiec został egzaminatorem w komisji egzaminacyjnej dla nauczycieli gimnastyki w szkołach średnich. Posiadał wielkie walory wychowawcze, przyczynił się do zwiększenia liczby członków „Sokoła”, a wśród sokolstwa i społeczeństwa stał się niezmiernie popularny. A.M. Durski zmarł 6 listopada 1908 r. we Lwowie (Wolańczyk 1948, s. 11).

W lwowski ruch higieniczny był również zaangażowany inny nauczyciel wychowania fizycznego - Edmund Cenar. Urodził się w 1856 r. Hermannsztadzie (Rumunia). Od roku 1880 pracował w Seminarium Nauczycielskim we Lwowie. Przywiązywał szczególnie wielką wagę do zdrowotno-higienicznej i wychowawczej funkcji ćwiczeń fizycznych. Był gorącym zwolennikiem gier i zabaw na świeżym powietrzu oraz racjonalnych ćwiczeń gimnastycznych, przystosowanych do potrzeb wieku szkolnego. Za jego staraniem wychowanie fizyczne wprowadzono do miejskich szkół Lwowa jako przedmiot obowiązkowy. Pełnił obowiązki inspektora gimnastyki w szkołach miejskich, był członkiem, a następnie sekretarzem Państwowej Komisji Egzaminacyjnej dla kandydatów na nauczycieli gimnastyki w szkołach średnich i seminariach nauczycielskich we Lwowie. Będąc działaczem Towarzystwa Pedagogicznego we Lwowie organizował korpusy wakacyjne i kolonie letnie dla młodzieży szkół lwowskich. Jako jeden z pierwszych kierowników kolonii wakacyjnych przyczynił się do nadania tej instytucji charakteru higieniczno-wychowawczego. Z jego inicjatywy w 1890 r. powstało pierwsze boisko korpusów wakacyjnych, które stało się zalążkiem przyszłego Parku im. H. Jordana we Lwowie. Projekt tego parku był też dziełem Cenara. Był inicjatorem wyodrębnienia żeńskich oddziałów gimnastycznych w „Sokole”, co wynikało z właściwej oceny odmiennego charakteru ćwiczeń fizycznych dla kobiet (Ksiegga... 1892). Ponadto Cenar jest znany jako autor ponad 20 podręczników i ok. 50 artykułów i rozpraw poświęconych problematyce 
wychowania fizycznego. Liczne rozprawy i artykuły dotyczące wychowania fizycznego E. Cenar publikował również na łamach czasopism, tj.: „Przewodnik Gimnastyczny Sokół”, „Szkoła”, „Muzeum”, „Rodzina i Szkoła”. Zmarł 6 października 1913 r. we Lwowie.

We Lwowie w ruch higieniczny był zaangażowany też Bronisław Kaczorowski, lekarz stomatolog. Urodził się w 1857 r. w Mielcu. W latach 1893-1914 mieszkał we Lwowie i tam włączył się w szkolny ruch higieniczny. Jako pierwszy lekarz szkolny w Galicji rozpoczął systematyczne badania uczniów w gimnazjach lwowskich. Wyniki jego badań stanowiły podstawę wielu działań mających na celu poprawę zdrowotności dzieci i młodzieży. Kaczorowski jest uznawany za ojca metodyki wychowania zdrowotnego. Opublikował dwa podręczniki do higieny: Elementarz higieniczny dla dzieci szkolnych (Lwów 1908) oraz Elementarz higieniczny dla młodzieży szkolnej (Lwów 1910). W podręcznikach tych przekazywał podstawową wiedzę z zakresu higieny i ochrony zdrowia. Był czynnym członkiem Towarzystwa Przyjaciół Zdrowia we Lwowie oraz Warszawskiego Towarzystwa Higienicznego. Redagował „Przegląd Higieniczny”, na którego łamach publikował liczne artykuły z zakresu higieny szkolnej, oraz warszawskie pismo „Przyjaciel Zdrowia Ludu", które było organem Ministerstwa Zdrowia Publicznego. W periodyku tym wprowadził specjalny „kącik higieniczny dla dzieci”, w którym zamieszczał treści o tematyce higieniczno-zdrowotnej.

W ruch higieniczny zaangażował się czynnie, uczestnicząc też w Zjazdach Lekarzy i Przyrodników Polskich. W 1914 r. był współorganizatorem i sekretarzem generalnym I Zjazdu Higienistów Polskich we Lwowie. Podczas wojny prowadził szpital wojskowy w Mostach Wielkich. Po wojnie pracował w Ministerstwie Zdrowia Publicznego oraz jako lekarz powiatowy. Zmarł w Warszawie w 1932 r. (Demel 2000, s. 83).

Drugim ośrodkiem ruchu higienicznego w Galicji był Kraków. W działalności na rzecz poprawy zdrowia i higieny wyróżniał się tutaj Józef Dietl, który urodził się 24 stycznia 1804 r. w Podbużu (Samborskie). W 1829 r. otrzymał stopień doktora medycyny i jako adiunkt wykładał historię naturalną w Uniwersytecie Wileńskim. W 1833 r. został fizykiem powiatowym w Wiedniu, a w $1841 \mathrm{r}$. naczelnym lekarzem wiedeńskiego szpitala (Wrzosek 1939-1945, s. 158-166). W 1851 r. Dietl objął katedrę medycyny wewnętrznej i anatomii patologicznej na Uniwersytecie Jagiellońskim. Był jednym z najznakomitszych klinicystów polskich; jako lekarz uzyskał rozgłos w całym kraju. Dążył do przekształcenia medycyny w naukę ścisłą i do jej zreformowania. W 1860 r. J. Dietl został wybrany dziekanem wydziału lekarskiego Uniwersytetu Jagiellońskiego w Krakowie, a w 1861 rektorem. Był obdarzony świetnym talentem organizatorskim i miał wielkie zasługi dla rozwoju uniwersytetu (Korczyński 1899, s. 145-172). Na wyróżnienie zasługują m.in. jego działania 
na rzecz unarodowienia szkolnictwa. Dietl był również posłem na Sejm galicyjski, a następnie członkiem delegacji tego Sejmu do Rady Państwa. W jego ławach walczył o unarodowienie szkolnictwa średniego i wyższego oraz domagał się pełnej autonomii Galicji. Postulował także polepszenie bytu nauczycielstwa. Za śmiałą działalność polonizacyjną w 1865 r. rząd austriacki usunął Dietla z uczelni. Nie przerwał on jednak działalności lekarskiej i społecznej. W latach 1866-1874, będąc prezydentem Krakowa, nakreślił i zrealizował plany budowy wodociągów, kanalizacji, rzeźni, szkół, propagował konieczność kształcenia dziewcząt, opracował zasady reformy szkolnictwa w monografii O reformie szkót krajowych (Kraków 1865-1866). Od 1872 r. Dietl był członkiem czynnym, a następnie dyrektorem wydziału matematyczno-przyrodniczego Akademii Umiejętności. W swej działalności na rzecz poprawy zdrowotności ludności poświęcił wiele uwagi uzdrowiskom galicyjskim. W oddzielnych broszurach wydał opisy źródeł leczniczych w Szczawnicy, Iwoniczu, Krzeszowicach, Swoszowicach, Solcu, Rabce, opis zakładu hydropatycznego w Ojcowie oraz obszerną monografię Krynicy. Przekonywał w nich o właściwościach leczniczych wód $\mathrm{z}$ wymienionych źródeł. We wszystkich pracach podkreślał również znaczenie odpowiedniego odżywiania, stylu i warunków życia dla utrzymania zdrowia. Dokonał pierwszej klasyfikacji polskich wód leczniczych, zyskując miano ojca balneologii polskiej (Szumowski 1938, s. 1-12). Dietl był ponadto autorem licznych prac z zakresu anatomii patologicznej i medycyny. Wśród nich są również publikacje poświęcone higienie. Zmarł w 1878 r. w Krakowie.

Na polu higieny w Krakowie działał również lekarz higienista Henryk Jordan. Urodził się w Przemyślu w 1842 r. W 1870 r. otrzymał dyplom doktora medycyny. Jako lekarz cieszył się ogromnym powodzeniem, służył pomocą rodzinom najbiedniejszym, robotniczym. Od 1881 r. był wykładowcą na Wydziale Lekarskim Uniwersytetu Jagiellońskiego (Smarzyński 1958, s. 74). W ramach społecznej działalności pedagogicznej na terenach otrzymanych od Gminy Miejskiej według własnego projektu i z własnych funduszy utworzył w 1889 r. park, któremu Rada Miejska nadała nazwę Park Miejski dra Henryka Jordana. Park był ośrodkiem wypoczynku i rekreacji dla dzieci i młodzieży szkolnej oraz młodzieży rzemieślniczej. Była to nowoczesna instytucja wychowania pozaszkolnego koncentrująca się na wychowaniu zespołowym i wszechstronnym rozwoju jednostki, oferująca uczestnikom różnorodne formy aktywności. Na program zajęć składały się gry zespołowe i indywidualne oraz ćwiczenia gimnastyczne dla dzieci w wieku 5-18 lat (Godycki 1939, s. 27). Zajęcia były tak przemyślane, że cała młodzież biorąca w nich udział kolejno zmieniała boiska, mając możliwość uczestnictwa w różnorodnych ćwiczeniach i zabawach. W parku obowiązywał wewnętrzny regulamin, który określał zasady korzystania z zajęć w celu utrzymania porządku (Jordan 1894, s. 59-64). 
W niedzielę w zajęciach w parku uczestniczyła młodzież rzemieślnicza, która była zwykle zaniedbana wychowawczo i pozbawiona rozrywek w dni wolne od pracy (Wyrobek 1927, s. 187). Chcąc zachować ciągłość pracy, w okresie zimowym Jordan organizował ślizgawkę oraz zajęcia w salach parku. Dbając o zdrowie i higienę, w głównym pawilonie urządził pomieszczenia kąpielowe i natryski. Zarząd parku dbał również o dożywianie młodzieży. Każdy z uczestników mógł za drobną opłatą nabyć szklankę mleka z bułką, dla najbiedniejszych te posiłki dawano za darmo. Teoretyczne uzasadnienie swojej idei Jordan przedstawił w odczycie O zabawach młodzieży, który wygłosił we Lwowie w 1891 r. W zakończeniu referatu stwierdził: „Chowajmy inaczej naszych synów i córki, nie pozwalajmy im mitrężyć dnia całego przy książkach, owszem niech się uczą, ale dążmy do tego, by czas nauki inaczej rozłożono, by nasza młodzież codziennie się bawiła rozsądnie, higienicznie, a i przeciążenie zniknie i zdrowie się poprawi” (Jordan 1891, s. 33-52).

Powodzenie parku było olbrzymie. Już w pierwszych latach jego istnienia średnio przebywało w nim 500-900 osób dziennie, w następnych latach liczba ta dochodziła do 2000 osób (Godycki 1939, s 28). Krakowianie na początku byli nieufni wobec tego miejsca, jednak z biegiem czasu nieufność zmieniła się w zainteresowanie. Tłumy dorosłych przychodziły, aby przyglądać się harcom dzieci i młodzieży (Talarczykowna 1939, s. 16). Coraz częściej pojawiały się pochlebne opinie na temat Parku Jordana w prasie. W „Przeglądzie Lekarskim” z 1889 roku czytamy: „Kto widział te dzieci przed kilkoma miesiącami wątłe i niezgrabne, $w$ ruchach gnuśne i leniwe, a dziś tak odważne, energiczne i zręczne, ten uzna z jednej strony wartość metody ćwiczeń, dającej tak pomyślne wyniki, a z drugiej oceni wysoką działalność instytucji dra Jordana na drodze naszego fizycznego odrodzenia" (NN 1889, s. 439).

Dzieło Jordana podziwiano i naśladowano zagranicą, zwłaszcza w Niemczech, Austrii, Szwajcarii i Francji. Wzorem Parku Jordanowskiego powstały również ogrody dla dzieci i młodzieży w wielu miastach polskich. Po zakończeniu II wojny światowej idea Jordana ożyła, ogródki jordanowskie przekształciły się w place zabaw dla młodszych dzieci, powstały niemal w każdym polskim mieście.

Poza działalnością w parku, Jordan prowadził też działalność społecznikowską na innym polu. Należał do Towarzystwa Nauczycieli Szkół Wyższych i brał udział w pracach nad reformą szkół średnich galicyjskich jako delegat Uniwersytetu Jagiellońskiego oraz członek Towarzystwa Pedagogicznego. Był inicjatorem wprowadzenia do szkół średnich w Krakowie obowiązkowych lekcji gimnastyki oraz stanowiska lekarzy szkolnych, był również inicjatorem kształcenia nauczycieli wychowania fizycznego. Jordan był też autorem kilkunastu prac z zakresu medycyny, higieny oraz wychowania fizycznego. W $1906 \mathrm{r}$. został powołany do Najwyższej Rady Sanitarnej w Wiedniu jako jeden z pierwszych Polaków, co było wyrazem 
wielkiego uznania jego wiedzy i pracy na polu propagowania higieny społecznej. Zmarł 18 maja 1907 r. w Krakowie.

W działalność higieniczną był również zaangażowany Eugeniusz Witold Piasecki. Urodził się 13 listopada 1872 r. we Lwowie. Był lekarzem i nauczycielem gimnastyki podobnie jak ojciec - Wenanty Piasecki. Od 1899 r. E. Piasecki mieszkał we Lwowie, pracował jako nauczyciel gimnastyki w IV Państwowym Gimnazjum, a od 1912 r. jako inspektor wychowania fizycznego szkól średnich Galicji oraz wiceprezes państwowej komisji egzaminacyjnej dla nauczycieli wychowania fizycznego. Opublikował kilka prac z zakresu higieny, z których warto wymienić Stan obecny higieny szkolnej w Galicji (Lwów 1907), Epidemia płonicy we Lwowie 1907-1909 („Głos Lekarzy” 1909), Zdobycze lat ostatnich w zakresie walki z chorobami ostremi zakaźnemi w szkole („Zdrowie” 1909). W latach 1905-1915 Piasecki wykładał higienę szkolną oraz teorię wychowania fizycznego dla studentów Wydziałów Filozoficznego oraz Lekarskiego na Uniwersytecie Lwowskim, równocześnie prowadził badania naukowe. Działalność naukowo-badawcza E. Piaseckiego była związana głównie z higieną szkolną, wychowaniem fizycznym i zagadnieniami medycznymi. W dziedzinie higieny szkolnej dążył do ścisłego określenia kryteriów, jakim powinny odpowiadać warunki procesu wychowawczego i stosowane ćwiczenia z punktu widzenia wymogów nowoczesnej higieny. Publikował wiele artykułów o tematyce higienicznej w czasopismach: „Szkoła”, „Przegląd Pedagogiczny”, „Przegląd Higieniczny”, „Lwowski Tygodnik Lekarski”, „Muzeum”. E. Piasecki stworzył własny system wychowania fizycznego przez umiejętne połączenie opartego na znajomości anatomii fizjologii człowieka systemu szwedzkiego Linga $\mathrm{z}$ bogatym w zespół gier ruchowych i sportów na świeżym powietrzu systemem angielskim. Napisał pierwsze polskie opracowanie poświęcone wychowaniu fizycznemu Zasady wychowania fizycznego (Kraków 1904). Stał się twórcą w Polsce, a współtwórcą w Europie nowej dziedziny nauki, teorii wychowania fizycznego o charakterze interdyscyplinarnym, łączącej anatomię, fizjologię, higienę, nauki przyrodnicze z pedagogiką, psychologią, socjologią.

Inny nurt badawczy był związany ze skautowską metodą wychowawczą, którą Piasecki starał się unarodowić i jako harcerstwo włączyć do całego systemu wychowawczego młodzieży. Był członkiem wielu organizacji społeczno-pedagogicznych. W 1904 r. założył we Lwowie Towarzystwo Zabaw Ludu i Młodzieży (potem Towarzystwo Zabaw Ruchowych) z boiskami i urządzeniami sportowymi i był jego pierwszym prezesem. Wraz z Kazimierzem Pankiem i Kazimierzem Wyrzykowskim przeszczepił do Galicji Wschodniej ogrody jordanowskie oraz warsztaty szkolne. Był jednym z pionierów gry piłki nożnej we Lwowie, wprowadził ją do zajęć szkolnych, popularyzował też ten sport wśród młodzieży pozaszkolnej. 
W latach 1906-1915 E. Piasecki był radnym miasta Lwowa. Wiele jego inicjatyw i nowatorskich rozwiązań w dziedzinie higieny społecznej, zdrowia publicznego i wychowania fizycznego doczekało się wówczas realizacji, np. od 1907 r. z jego inicjatywy wprowadzono we Lwowie instytucję lekarza szkolnego w szkołach ludowych oraz ścisły nadzór lekarski nad zabezpieczeniem urządzeń higienicznych w nowo wybudowanych szkołach.

W 1919 r. został powołany jako profesor nadzwyczajny na kierownika Katedry Higieny Szkolnej i Teorii Wychowania Fizycznego przy Wydziale Filozoficznym Uniwersytetu Poznańskiego, od 1922 r. pracował jako profesor zwyczajny z przeniesieniem na Wydział Lekarski katedry, którą zajmował do śmierci. Był twórcą jednolitego planu badawczego dla wychowania fizycznego jako dyscypliny.

Eugeniusz Piasecki był też zaangażowany w działalność licznych organizacji społecznych związanych z kulturą fizyczną. W 1938 r. wydział fizjologiczny Komitetu Nagrody Nobla wysunął jego kandydaturę w zakresie medycyny, ale wybuch wojny przerwał tok tej sprawy. E. Piasecki zmarł w Poznaniu 17 lipca 1947 r. (Toporowicz 1988, s. 379).

W działalność na rzecz rozwoju wychowania fizycznego oraz sportu szkolnego i idei skautingu był zaangażowany ponadto Zygmunt Wyrobek. Urodził się w $1872 \mathrm{r}$. w Krakowie. Od 1901 r. przez 24 lata pracował jako nauczyciel gimnastyki w Męskim Seminarium Nauczycielskim w Krakowie. Pełnił też przez kilka lat funkcję kierownika Parku Jordana w Krakowie po śmierci jego twórcy. Od 1890 r. był aktywnym członkiem Towarzystwa Gimnastycznego „Sokół” w Krakowie. W okresie tym aktywnie pracował nad rozwojem teorii i praktyki wychowania fizycznego, a szczególnie gier i zabaw ruchowych (Krzanowski 2002, s. 201). Będąc w latach 1897-1901 współpracownikiem „Przeglądu Gimnastycznego”, opublikował wiele artykułów na temat różnych aspektów ćwiczeń fizycznych. Jako rzecznik reformy systemu gimnastycznego postulował wprowadzenie do programu wychowania fizycznego w szerokim zakresie gier i zabaw ruchowych. W swych artykułach dał nie tylko opis i systematykę gier i zabaw, lecz także opracował metodę ich nauczania. Z. Wyrobek aktywnie pracował również w ruchu harcerskim. Dzięki niemu w Krakowie powstało kilkanaście drużyn harcerskich. Od 1925 r. pracował w Kuratorium Okręgu Szkolnego Krakowskiego, m.in. na stanowisku wizytatora wychowania fizycznego. Był wtedy inicjatorem okręgowych igrzysk sportowych młodzieży szkolnej oraz Ognisk Metodycznych Wychowania Fizycznego. W spuściźnie swej pozostawił wiele różnych publikacji dotyczących zagadnień higienicznych. Z. Wyrobek zmarł 19 stycznia 1939 r. w Krakowie (Grot-Toporowicz 1967, s. 115-116).

W działalność na rzecz poprawy zdrowia i higieny w Galicji byli zaangażowani przedstawiciele różnych grup społecznych. Wśród nich wyróżniali się lekarze, higieniści i pedagodzy. Ich działalność z biegiem lat przynosiła wymierne efekty 
w postaci przeobrażeń sanitarno-higienicznych. Stopniowo wzrastała świadomość społeczna w zakresie dbałości o własne zdrowie i warunki życia. Dostrzeżono również problem higieny szkolnej. Zrozumiano, że nieodpowiednie warunki higieniczno-zdrowotne w szkołach utrudniają prawidłowy rozwój dzieci i młodzieży oraz przyczyniają się do powstawania chorób. W związku z tym stopniowo zaczęto poprawiać sytuację higieniczną w szkołach.

Na podstawie analizy materiałów źródłowych można uznać, że w popularyzacji zdrowia i higieny w Galicji przodowały dwa ośrodki - lwowski i krakowski. We Lwowie działał autor pierwszego polskiego podręcznika higieny szkolnej, pionier myśli higienicznej w Galicji - Tadeusz Żuliński. W działalność higieniczną byli zaangażowani poza tym inni wybitni lekarze, higieniści, teoretycy i praktycy wychowania fizycznego, m.in.: Józef Żuliński, Edward Madeyski, Mieczysław Baranowski, Adam Baranowski, Bronisław Kaczorowski. W Krakowie znaną postacią stał się Henryk Jordan. Oprócz niego w pracę społeczną na rzecz krzewienia higieny byli zaangażowani: Eugeniusz Piasecki, Józef Dietl, Zygmunt Wyrobek. Analizując wszystkie działania przedstawionych osób, można stwierdzić, że Galicja stała się wręcz centrum polskiego ruchu higienicznego. Dzięki autonomii miała większe niż inne zabory możliwości wymiany myśli i doświadczeń. Społecznicy wykorzystali to, podejmując różnorodne inicjatywy. Dzięki ich zaangażowaniu rozwinęła się teoria i praktyka higieniczna, która zmieniała stopniowo rzeczywistość higieniczno-zdrowotną Galicji.

\section{LITERATURA}

Baranowski B., 1884, Kolonie wakacyjne. Uwagi o potrzebie i sposobach urządzania w naszym kraju. Lwów, Wyd. Nakładem Towarzystwa Pedagogicznego, I Związkowa Drukarnia we Lwowie.

Baranowski B., 1911, Szkolnictwo ludowe w Galicji w swym rozwoju liczebnym od roku 1868 do roku 1909 z uwzględnieniem stosunków higienicznych. Lwów, Wyd. Nakładem Wydawnictwa „Rodziny i Szkoły”, Drukarnia Udziałowa we Lwowie. Baranowski M., 1881, Zarys higieny i dietetyki ciała i ducha w zastosowaniu do młodzieży szkolnej i do wieku dziecięcego. Stanisławów, Wyd. Nakładem dra J. Dankiewicza.

Baranowski M., 1885, Jakie następstwa pod względem wplywu na zdrowie dzieci sprowadza przepetnienie klas w szkole. „Szkoła”, nr 28, 231.

Baranowski M., 1888, O ławkach szkolnych i ich wplywie na zdrowie młodzieży. „Szkoła”, nr 22, 186-187.

Baranowski M., 1894, Higiena szkolna. „Szkoła”, nr 24, 271. 
Bruchnalski K., 1935a, Baranowski Bolesław (1844-1916). W: Polski słownik biograficzny, t. 1. Kraków, Polska Akademia Umiejętności, 276-277.

Bruchnalski K., 1935b, Baranowski Mieczysław Tytus (1851-1898). W: Polski słownik biograficzny, t. 1. Kraków, Polska Akademia Umiejętności, 282-283.

Cenar E., 1907, Działalność Edwarda Madeyskiego na polu gimnastyki, Dodatek do „Przewodnika Gimnastycznego Sokół”, nr 1.

Demel M., 2000, Z dziejów promocji zdrowia w Polsce. Kraków, Akademia Wychowania Fizycznego im. B. Czecha.

Dolata E., 2002, Tadeusz Żuliński - biogram. W: Opieka nad dzieckiem w Galicji. Rzeszów, Wydawnictwo Uniwersytetu Rzeszowskiego, 207-213.

Dolata E., 2010, Czasopisma galicyjskie wobec problemów higieny szkolnej. W: I. Michalska, G. Michalski (red.), Czasopiśmiennictwo XIX i XX wieku jako źródło do historii edukacji. Łódź, Wydawnictwo Uniwersytetu Łódzkiego, 253-264.

Dolata E., 2011, Józef Żuliński i jego wkład w organizację kolonii dziecięcych w Galicji, „Rocznik Komisji nauk Pedagogicznych”, t. 54. Kraków, Polska Akademia Nauk, 17-30.

Fijałek J., 1998, Tradycje zdrowia publicznego w historii medycyny powszechnej i polskiej. Łódź, Akademia Medyczna.

Godycki M., 1939, W pięćdziesięciolecie Parku Jordana. „Higiena Szkolna”, t. 1, z. 1. Poznań, 27-32.

Górski W., 1927, Niepospolita rodzina. Monografia rodziny Żulińskich. Warszawa, Zakłady Drukarskie Wyszyński i S-ka.

Grot-Toporowicz K., 1967, Wyrobek Zygmunt. W: R. Wroczyński (red.), Słownik biograficzny wychowania fizycznego i sportu. Warszawa, Wydawnictwo PWN, 115-116.

Gutkowski J., 1893, Korpusy wakacyjne dla uczniów szkół ludowych miasta Lwowa. „Szkoła”, nr 9.

Jordan H., 1891, O zabawach młodzieży. „Przewodnik Higieniczny”, nr 2, 33-52.

Jordan H., 1894, Miejski Park dr Jordana w Krakowie. Kraków, Nakładem dra H. Jordana.

Kacprzak M., 1932, O higienie i zawodzie higienisty. Warszawa, Drukarnia „Siła”. Korczyński L., 1899, Zarys dziejów kliniki Lekarskiej Uniwersytetu Jagiellońskiego od jej założenia do 1875 roku. Kraków, Drukarnia Uniwersytetu Jagiellońskiego pod zarz. Józefa Filipowskiego, 145-172.

Krzanowski A., 2002, Zygmunt Wyrobek (1872-1939). W: A. Meissner (red.), Opieka nad dzieckiem w Galicji. Rzeszów, Wydawnictwo Uniwersytetu Rzeszowskiego. Księga pamiątkowa ku uczczeniu dwudziestej piątej rocznicy założenia Towarzystwa Gimnastycznego Sokół we Lwowie, 1892. Lwów, Towarzystwo Gimnastyczne „Sokół”. 
Marcinkowski T., 1988, Początki profilaktyki i medycyny społecznej. W: T. Brzeziński (red.), Historia medycyny. Warszawa, Zakład Wydawnictw Lekarskich, 250-260. Meissner A., 1997, Bolesław Adam Baranowski - przedstawiciel galicyjskiej pedagogiki urzędniczej. W: Cz. Majorek, J. Potoczny (red.), Biografie pedagogiczne, seria: Galicja i jej dziedzictwo, t. 9. Rzeszów, Wydawnictwo Wyższej Szkoły Pedagogicznej, 81-92.

NN, 1889, Wiadomości potoczne. „Przegląd Lekarski” nr 36, 439.

NN, Wspomnienie pośmiertne, „Szkoła” 1898, nr 49.

Potoczny J., 1997, Pedagogiczne wyznania Mieczysława Tytusa Baranowskiego. W: Cz. Majorek, J. Potoczny (red.), Biografie pedagogiczne, seria: Galicja i jej dziedzictwo, t. 9. Rzeszów, Wydawnictwo Wyższej Szkoły Pedagogicznej, 103-110. Pótwiekowa działalność Towarzystwa Kolonii Leczniczych dla Dzieci we Lwowie 1885-1935, 1935. Lwów, Towarzystwo Kolonii Leczniczych dla Dzieci we Lwowie. Regulamin Korpusów wakacyjnych młodzieży szkolnej miasta Lwowa, 1893. Lwów. Smarzyński H., 1958, Henryk Jordan - pionier nowoczesnego wychowania fizycznego $w$ Polsce. Kraków, Wydawnictwo PWN.

Szczepańska B., 2014, Higiena szkolna w Drugiej Rzeczypospolitej. Łódź, Wydawnictwo Uniwersytetu Łódzkiego.

Szumowski W., 1938, Józef Dietl jako ojciec balneologii polskiej. Kraków.

Talarczykówna R., 1939, Zasługi Henryka Jordana na polu higieny i wychowania fizycznego młodzieży. „Higiena Szkolna”, t. 1, z. 1, 16-17.

Terlecki R., 1990, Oświata dorostych i popularyzacja nauki w Galicji w okresie autonomii. Wrocław, Zakład Narodowy im. Ossolińskich.

Toporowicz K., 1974, Madeyski Edward. W: Polski stownik biograficzny. WrocławWarszawa-Kraków-Gdańsk, Polska Akademia Nauk, 120-121.

Toporowicz K., 1988, Eugeniusz Piasecki (1872-1947) życie i dzieło. Warszawa-Kraków, Wydawnictwo PWN.

Vigarello G., 1998, Czystość i brud. Higiena ciała od średniowiecza do XX wieku. Warszawa, Wydawnictwo W.A.B.

Wolańczyk M., 1948, Durski Antoni Maciej. W: Polski Słownik Biograficzny, t. 6. Kraków, Polska Akademia Umiejętności, 11.

Wroczyński R., 1975, Henryk Jordan - propagator gier i zabaw ruchowych. Warszawa, Nasza Księgarnia.

Wrzosek A., 1939-1946, Józef Dietl. W: Polski słownik biograficzny, t. 5. Kraków, Polska Akademia Umiejętności, 158-166.

Wyrobek Z., 1927, Podjęcie idei Jordanowskiej - zadaniem sekcji wychowania fizycznego i higieny szkolnej. „Wychowanie Fizyczne”, z. 7-8, 187. 


\title{
GALICIAN POPULARIZERS OF HEALTH AND HYGIENE \\ AT THE TURN OF THE $19^{\text {TH }}$ AND $20^{\text {TH }}$ CENTURY
}

\begin{abstract}
At the turn of the $19^{\text {th }}$ and $20^{\text {th }}$ century, Galicia became the centre of the Polish hygienic movement, the aim of which was to improve the hygienic situation of the country. On the one hand, owing to the autonomy, it had greater opportunities than other partitioned parts of Poland to exchange ideas and experience, and on the other hand, the difficult living conditions of the population and the very bad sanitary and hygienic situation of the cities and villages imposed a necessity to take drastic actions in this scope. The Polish hygienists, doctors and educators joined the actions for improvement of the hygienic conditions in Galicia. The article presents the chosen figures and the popularizing actions for health and hygiene in two centres, i.e. Cracow and Lviv. Tadeusz Żuliński, the author of the first schoolbook on school hygiene, a pioneer of the hygienic thought in Galicia, acted in Lviv. Furthermore, the following persons were engaged in the hygienic action: Józef Żuliński, Edward Madeyski, Mieczysław Tytus Baranowski, Bolesław Adam Baranowski, Bronisław Kaczorowski, Edmund Cenar, Antoni Durski. Henryk Jordan, the professor of the Faculty of Medicine of the Jagiellonian University, became a famous person in Cracow. Apart from him, Eugeniusz Piasecki, Józef Dietl and Zygmunt Wyrobek were involved in social work for promoting hygiene.
\end{abstract}

Keywords: history of education, hygiene, hygienic education, hygienic movement in Galicia 
